\title{
Erratum to: In vitro activity of antimicrobial agents against Legionella isolated from environmental water systems: first results from Turkey
}

\author{
Haluk Erdogan • Fusun Can • Muge Demirbilek • \\ Funda Timurkaynak $\cdot$ Hande Arslan
}

Published online: 7 March 2010

(C) Springer Science+Business Media B.V. 2010

\section{Erratum to: Environ Monit Assess \\ DOI 10.1007/s10661-009-1293-y}

It has recently come to the authors' attention that a study was published in 2006 concerning water samples taken from Istanbul. While the articles are different, and the present article covers a much wider geographical basis, the authors recognize that the subtitle of their paper 'First results from Turkey' could be misinterpreted.

The online version of the original article can be found at http://dx.doi.org/10.1007/s10661-009-1293-y.

\footnotetext{
H. Erdogan · F. Timurkaynak · H. Arslan Department of Infectious Diseases and Clinical Microbiology, Baskent University Faculty of Medicine, Ankara, Turkey

F. Can · M. Demirbilek

Department of Microbiology and Clinical Microbiology, Baskent University Faculty of Medicine, Ankara, Turkey

H. Erdogan $(\varangle)$

Baskent Universitesi Alanya Araştırma ve Uygulama Merkezi, Saray m, Kizlarpinari cd, No:1, Alanya, 07400 Antalya, Turkey

e-mail: erdoganhaluk@hotmail.com
}

The study concerning Istanbul was published by Sehir Birteksöz, A, Zeybek, Z, and Çotuk, A, in the book chapter In vitro activities of various antibiotics against Legionella pneumophila published in the book entitled Legionella: State Of The Art 30 Years After Its Recognition, 2006, American Society for Microbiology, Washington, DC. 